\title{
The importance of early successional habitats to rare, restricted-range, and endangered birds in the Ecuadorian Andes
}

\author{
MARK R. WELFORD
}

\begin{abstract}
Summary
Since the mid-1980s, exhausted pastures in Ecuador have been increasingly abandoned, allowing forest regeneration. At approximately $2,200 \mathrm{~m}$ in the Tandayapa valley I surveyed four abandoned pastures to evaluate their use by birds. Each former pasture represented a different age of vegetation maturity. The number of bird species recorded in each successively older abandoned pasture increased but only half the number of species recorded in the undisturbed forest site was recorded in the most mature pasture. However, at least four restricted-range bird species were recorded in a single pasture. As pastures rapidly convert to secondary forest, more bird species and rarer bird species use them, even in highly disturbed areas where surrounding pristine forest constitutes less than $10 \%$ of local forest cover. Conservation efforts should then be directed toward them.
\end{abstract}

\section{Introduction}

Tropical forests in South America are being cleared at an alarming rate. Since the 1950s, more than 90\% of the forest of western Ecuador below $900 \mathrm{~m}$ has been clear-cut (P. Greenfield 2000 in litt., Wilson 1992). In the Chocó forest region of south-west Colombia and north-west Ecuador, over $40 \%$ of the forest has been cleared or heavily degraded (Salaman 1994), mostly as a consequence of unplanned colonization and large-scale logging operations along recently constructed roads (Stattersfield et al. 1998). However, the clearing is rarely complete and is often not permanent (Schelhas and Greenberg 1986). Patches of primary forest, secondary forest, abandoned pastures and crop fields, and managed forest, occur in many agricultural landscapes (Caufield 1986, Schelhas and Greenberg 1986). In the Tandayapa Valley, Ecuador, pastures and crop fields are being abandoned because new road construction has bypassed the valley. In Puerto Rico, the transition from extensive to intensive agricultural production is also leading to land abandonment (Thomlinson et al. 1996).

Several studies suggest that abandoned pastures and the subsequent secondary forest can constitute habitat islands (Uhl et al. 1988, Finegan 1992). The diversity of these habitat islands seems to be controlled by the degree to which these secondary forests are surrounded by primary forest, their size, and the degree and nature of human activities still occurring within them (Uhl et al. 1988; Finegan 1992). Few studies have addressed avian use of abandoned former pastures (Andrade and Rubio-Torgler 1993, Da Silva et al. 1996, Borges and Stoufer 1999). 
Da Silva et al. (1996) found that only a few avian frugivores use recently abandoned pastures but Guevara et al. (1992) found that frugivorous birds do visit isolated trees in pastures and deposit a significant number of rainforest seeds under their canopies. Da Silva et al. (1996) found that, as abandoned pastures convert to secondary forest, many more frugivorous bird species eat, nest, and defecate seeds within them. They suggest that an understanding of bird use and behaviour in altered landscapes is important if forests are to be managed to protect regional diversity in Amazonia.

In this study I identify the variation in the use of high-altitude $(>2,000 \mathrm{~m})$ abandoned Andean pastures by birds. The general aims were to establish whether abandoned Andean pastures are species rich and whether they have potential for ecotourism. Specifically the research objectives were to identify trends in species richness, in particular the number and composition of avian frugivore species, and identify whether restricted-range bird species use abandoned pastures.

\section{Study site and methods}

I conducted my study at Bellavista $\left(\mathrm{OO}^{\circ} \mathrm{O} 1^{\prime} \mathrm{S}, \mathrm{O}_{7} 8^{\circ} 4^{\prime} \mathrm{W}\right)$ at approximately $2,200 \mathrm{~m}$ elevation in the Tandayapa valley, $40 \mathrm{~km}$ west of Quito, Ecuador (Figure 1). The Tandayapa valley provides a continuum from lower montane (subtropical) to upper montane forest (temperate) communities (Best et al. 1996). Extensive deforestation has created a patchwork of cattle pastures, second-growth forest in places dominated by Chusquea sp. bamboo, and a few pristine forest remnants. Soils are deep, well-drained Andosols developed from volcanic ash deposits (Sarmiento 1997). A dry season occurs between mid-June and late September while the rainy season occurs between mid-October and late May (Sarmiento 1997). Recently many entrepreneurs have purchased large tracts of former pasture and stands of adjacent secondary forest in the Tandayapa valley because of the opportunity for ecotourism associated with birdwatching, as Quito is less than a two-hour drive away. In a recent bird survey of the valley, T. Nunnery (1999 in litt.) found more than 300 species of birds, including 15 restricted-range Chocó endemics, one restricted-range high central Andean endemic, and one restricted-range Tumbesian endemic, as well as six additional Chocó endemics considered near-threatened and two species considered vulnerable to extinction (Stattersfield et al. 1998). Only four restricted-range species of least concern, five near-threatened, and one vulnerable bird species were documented by T. Nunnery (1999 in litt.) in the upper Tandayapa valley above $2,200 \mathrm{~m}$.

At the study area, all the surveyed sites varied between 3 and 5 ha and lie at approximately the same elevation. Both the active pasture and the three abandoned pastures were surrounded by severely degraded wet forest. Sites will be identified below by the time in years since abandonment or disturbance as either a pasture or forest site. The active pasture, pasture 0 , had cattle present in it throughout the study period, whereas pasture 2, was only occasionally used as a horse pasture for the two previous years. At both pasture o and pasture 2, foxtail grass Setaria sphacelata was the dominant understorey plant, with grass covering approximately $70 \%$ of the ground surface at pasture 0 , but less than $30 \%$ at pasture 2 . At pasture 0 , the remainder of the surface was covered by 

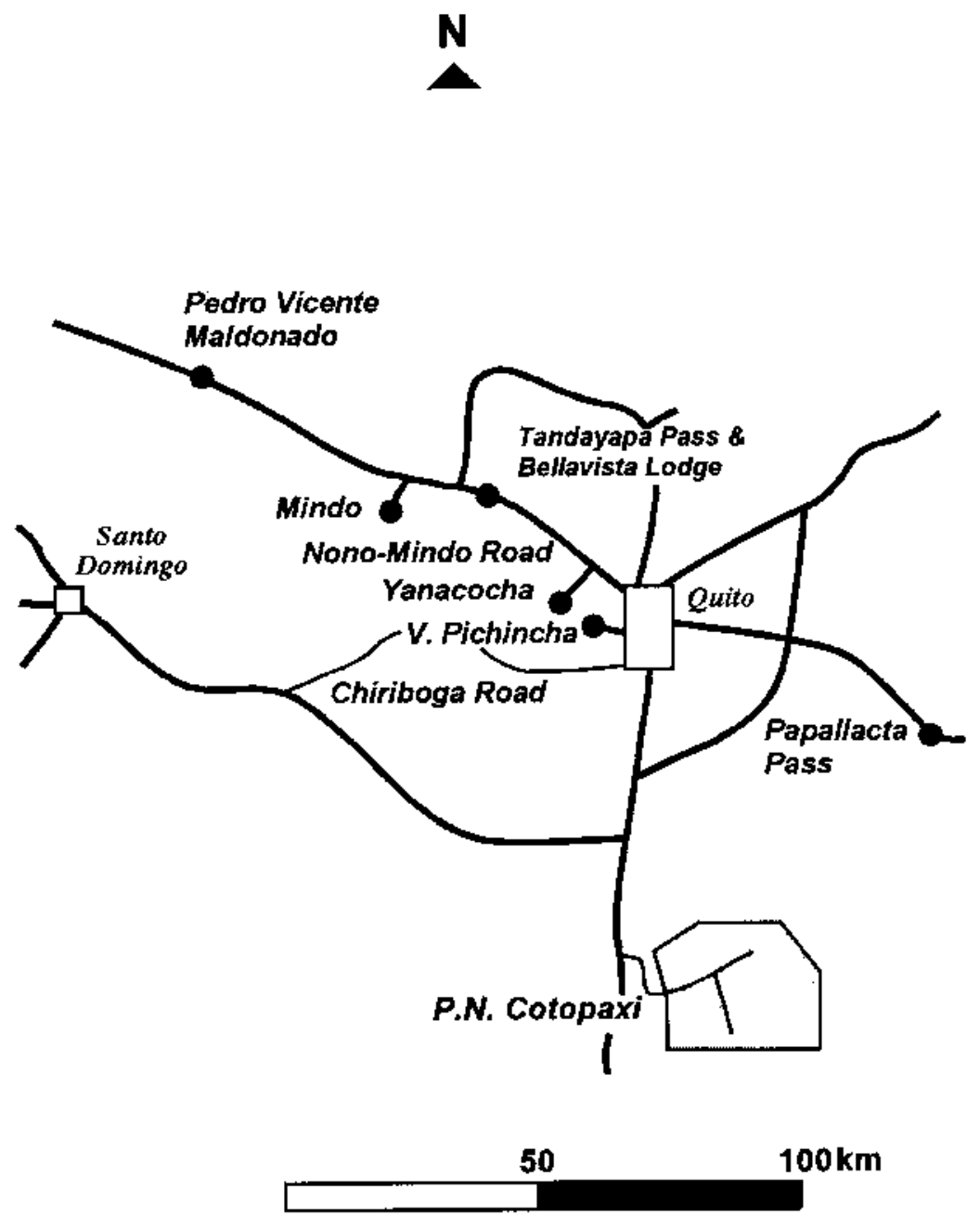

Figure 1. Map of Quito and Tandayapa Valley (modified from Best et al. 1996).

irregularly sized clumps of bracken Pteridium aquilium. Both pasture 5, abandoned for five years, and pasture 6, abandoned for six years, were dominated by small $<4 \mathrm{~m}$ high saplings creating a structurally complex environment. Both pastures 5 and 6 resemble secondary forest, with a dense, low cover of various woody (e.g. Baccharis polyantha, Cecropia sp.) and non-woody (e.g. Alloplectus tertagonoides, Musaceae sp., Erato polymnoides) plant species.

Two reference sites were surveyed, a disturbed forest site, forest 20, which had not been selectively cut for at least 20 years (R. Parsons 1998 in litt.), and an undisturbed forest site, forest 50 . At the former site, understorey up to $4 \mathrm{~m}$ in height was dominated by an impenetrable tangle of vines, shrubs, bamboo and tree ferns. At the latter site, there was no evidence of tree stumps, nor any bamboo, and epiphytic coverage was very well developed. Furthermore, trees attained heights of $15 \mathrm{~m}$, and understorey was sparse. 
The sites were surveyed in July 1998, following methods in Parker (1991) and Poulsen and Krabbe (1997). At each survey site, I tape-recorded the dawn chorus between $5 \mathrm{~h}_{30}$ and $6 \mathrm{~h}_{30}$ and at the same time identified and counted different singing or calling individuals. I rechecked the tape-recordings to check the identity of each vocalization. In the spring of 1999, I checked each tape again during data analysis. Each site was visited every six days throughout July. At each site I returned to the same spot to record the dawn chorus, when I recorded and identified birds within a $50 \mathrm{~m}$ full circle.

In addition, throughout the daylight hours, I would return to each site and assemble qualitative species lists to supplement the dawn chorus recordings. As a result, my data are standardized with respect to area, altitude and effort (Poulsen and Krabbe 1997).

\section{Results}

In a total of 32 surveys, I recorded 97 species at the six sites. The number of species recorded in the pastures increased significantly with time since abandonment ( $\left.a=19.5, b=1.16, r^{2}=0.85, P=0.05\right)$ (Figure 2: "Total Species"). In pasture 0 , seven bird species were documented whilst in pasture 6, 32 species were recorded. Figure 2 also illustrates the change in species composition over time among the survey sites. For example, two bird species recorded in pasture o were also recorded in pasture 2, Chestnut-crowned Antpitta Grallaria ruficapilla and Spillmann's Tapaculo Scytalopus spillmanni. The greatest turnover in species is observed between pasture 5 and pasture 6, 15 species not being present in the older abandoned pasture (Figure 2: "Species Lost"). These included commonly recorded species in pasture 5 such as Black-crested Warbler Basileuterus nigrocristatus, Grey-breasted Wood-Wren Henicorhina leucophrys, Beryl-spangled Tanager Tangara nigroviridis (although seen at the lodge at the very edge of pasture 6), Common Potoo Nyctibius griseus, Golden Tanager Tangara arthus (again seen at the lodge) and White-sided Flower-Piercer Diglossa albilatera.

The most abundant bird species in each pasture are reported in Table 1. The data indicate that wood warblers, spinetails and tapaculos are the most abundant birds in abandoned pastures, whereas in the adjacent forest tanagers are most abundant. However, in pasture 6, although Russet-crowned Warbler Basileuterus coronatus was the most abundant species, Striped Treehunter Thripadectes holostictus, Masked Trogon Trogon personatus and Glossy Black-Thrush Turdus serranus, all greater than $12 \mathrm{~cm}$ in length, were also very abundant. Nonetheless, birds larger than $12 \mathrm{~cm}$ in length were typically more common in the forest sites. Only in pastures 5 and 6 were large birds such as guans, toucans, and quetzals recorded (Tables 2, 3). Furthermore, a Swallow-tailed Nightjar Uropsalis segmentata was observed roosting in pasture 6 throughout the study period.

I placed all species into one of six guilds: raptorial, granivore, omnivore, frugivore, nectarivore and insectivore (Table 2). The least structurally complex environment, pasture o, had only three guilds, whereas, the two forest sites and pasture 5 had a complete complement of guilds. There is also an increase in the number of frugivore species recorded in each successively older abandoned pasture.

The occurrences of restricted-range bird are given in Table 3. Few restricted- 


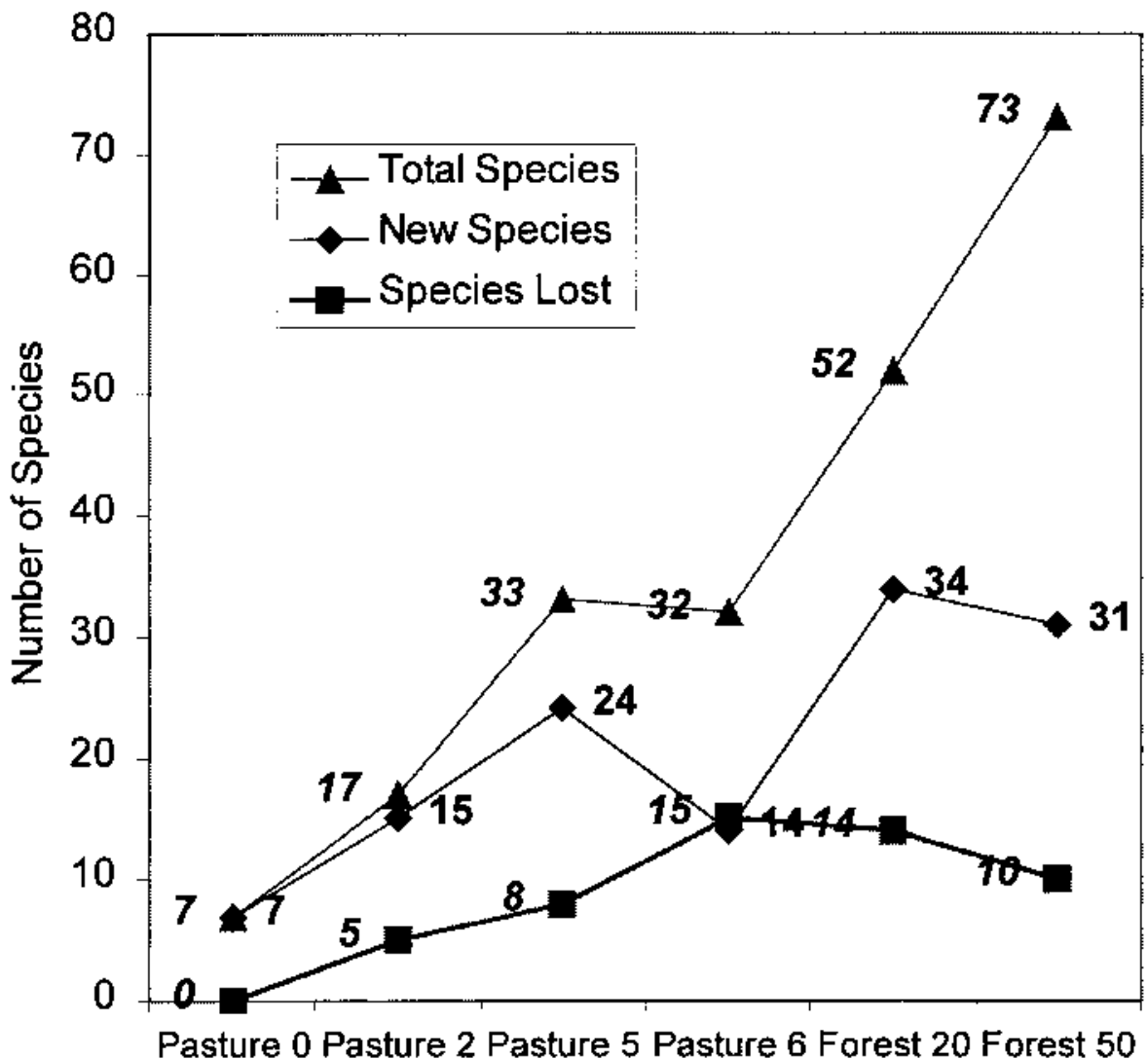

Figure 2. Total number of species observed at pasture and forest survey sites.

Table 1. Species abundance amongst each abandoned pasture

\begin{tabular}{|c|c|}
\hline Pasture & Abundant species \\
\hline \multirow[t]{2}{*}{ Pasture o } & Most abundant species: Azara's Spinetail Synallaxis azarae \\
\hline & Next most abundant species: Plain-tailed Wren Thryothorus euophrys \\
\hline \multirow[t]{2}{*}{ Pasture 2} & $\begin{array}{l}\text { Most abundant species: Slaty-throated Redstart Myioborus miniatus, Russet-crowned } \\
\text { Warbler Basileuterus coronatus }\end{array}$ \\
\hline & Next most abundant species: Yellow-bellied Chat-Tyrant Ochthoeca diadema \\
\hline \multirow[t]{2}{*}{ Pasture 5} & $\begin{array}{l}\text { Most abundant species: Spillman's Tapaculo Scytalopus spillmanni, Azara's Spinetail } \\
\text { Synallaxis azarae }\end{array}$ \\
\hline & Next most abundant species: Black-crested Warbler Basileuterus nigrocristatus \\
\hline Pasture 6 & Most abundant species: Russet-crowned Warbler Basileuterus coronatus \\
\hline Forest 20 & $\begin{array}{l}\text { Most abundant species: Russet-crowned Warbler Basileuterus coronatus, Beryl- } \\
\text { spangled Tanager Tangara nigroviridis, Blue-winged Mountain-Tanager Anisognathus } \\
\text { flavinucha, Dusky-bellied Bush Tanager Chlorospingus semifuscus }\end{array}$ \\
\hline Forest 50 & Most abundant species: Beryl-spangled Tanager Tangara nigroviridis \\
\hline & Next most abundant species: Speckled Hummingbird Adelomyia melanogenys \\
\hline
\end{tabular}


Table 2. Guild representation at each survey site (this excludes those birds seen along trails, or along the Nono-Mindo road, or at the lodge)

\begin{tabular}{llllcrr}
\hline Guilds & Pasture o & Pasture 2 & Pasture 5 & Pasture 6 & Forest 20 & Forest 50 \\
\hline Insectivore & 5 & 9 & 17 & 20 & 27 & 30 \\
Nectivore & 1 & 2 & 5 & 4 & 7 & 8 \\
Frugivore & 0 & $3^{*}$ & $11^{* *}$ & $12^{* * *}$ & 12 & 19 \\
Omnivore & 2 & 3 & 4 & 8 & 4 & 12 \\
Granivore & 0 & 0 & 1 & 0 & 1 & 2 \\
Raptorial & $\mathrm{O}$ & $\mathrm{O}$ & 1 & 0 & 1 & 2 \\
\hline
\end{tabular}

* Plumbeous Pigeon Columba plumbea, Orange-bellied Euphonia Euphonia xanthogaster, Grass-green Tanager Chlorornis riefferii.

** Crested Quetzal Pharomachrus antisianus, Golden-headed Quetzal Pharomachrus auriceps, Toucan Barbet Semnornis ramphastinus, Andean Solitaire Myadestes ralloides, Thick-billed Euphonia Euphonia laniirostris, Golden Tanager Tangara arthus, Golden-naped Tanager Tangara ruficervix, Berlyl-splanged Tanager Tangara nigroviridis, Blue-winged Mountain-Tanager Anisognathus flavinucha, Dusky-bellied Bush-Tanager Chlorospingus semifuscus, Grass-green Tanager Chlorornis riefferii.

*** Sickle-winged Guan Chamaepetes goudotii, Oilbird Steatornis caripensis, Crested Quetzal Pharomachrus antisianus, Masked Trogon Trogon personatus, Toucan Barbet Semnornis ramphastinus, Greenand-Black Fruiteater Pipreola riefferii, Orange-bellied Euphonia Euphonia xanthogaster, Golden Tanager Tangara arthus, Flame-faced Tanager Tangara parzudakii, Blue-winged Mountain-Tanager Anisognathus flavinucha, Dusky-bellied Bush-Tanager Chlorospingus semifuscus, Grass-green Tanager Chlorornis riefferii.

Table 3. Restricted-Range bird species defined as of Least Concern, Near-threatened or Vulnerable recorded at each site during the study period

\begin{tabular}{ll}
\hline Pasture & Restricted-range bird species \\
\hline Pasture o & \\
Pasture 2 & Least Concern: Giant Antpitta Grallaria giganteat \\
Pasture 5 & Least Concern: Dusky-bellied Bush-Tanager Chlorospingus semifuscus, Violet-tailed \\
& Sylph Aglaiocercus coelestis \\
& Near-threatened: Toucan Barbet Semnornis ramphastinus, Plate-billed Mountain- \\
& Toucan Andigena laminirostris, Beautiful Jay Cyanolyca pulchra $\neq$ \\
& Vulnerable: Tanager-Finch Oreothraupis arremonops* \\
Pasture 6 & Least Concern: Dusky-bellied Bush-Tanager Chlorospingus semifuscus **, Violet-tailed \\
& Sylph Aglaiocercus coelestis **, Gorgeted Sunangel Heliangelus strophianus** \\
& Near-threatened: Dark-backed Wood-Quail Odontophorus melanonotus, Toucan \\
& Barbet Semnornis ramphastinus, Beautiful Jay Cyanolyca pulchra**, Plate-billed Moun- \\
& tain-Toucan Andigena laminirostris** \\
Forest 20 & Least Concern: Violet-tailed Sylph Aglaiocercus coelestis, Black-chinned Mountain- \\
& Tanager Anisognathus notabilis, Dusky-bellied Bush-Tanager Chlorospingus semifuscus \\
& Near-threatened: Toucan Barbet Semnornis ramphastinus, Plate-billed Mountain- \\
& Toucan Andigena laminirostris \\
Forest 50 & Least Concern: Colombian Screech-Owl Otus ingens colombianus, Gorgeted Sunangel \\
& Heliangelus strophianus, Dusky-bellied Bush-Tanager Chlorospingus semifuscus, Giant \\
& Antpitta Grallaria gigantea \\
& Near-threatened: Toucan Barbet Semnornis ramphastinus, Plate-billed Mountain- \\
& Toucan Andigena laminirostris, Dark-backed Wood-Quail Odontophorus melanonotus \\
\hline
\end{tabular}

† Recorded along abandoned pasture edge.

$\ddagger$ Recorded in 1997 survey.

* Recorded along road adjacent to abandoned pasture.

** Recorded at Lodge. 
range bird species were recorded in pasture o or pasture 2. Four restricted-range species were recorded in pasture 5. In pasture 6, although only two nearthreatened, restricted-range species were recorded, five other restricted-range species were observed at the lodge at the very edge of pasture 6 . At the forest 20 site, I recorded five restricted-range species and seven restricted-range species at the forest 50 site.

\section{Discussion}

Bird diversity remained low for the first few years following abandonment of pastures, as Andrade and Rubio-Torgler (1994), Da Silva et al. (1996) and Borges and Stoufer (1999) found in Amazonian pastures and crop fields. However, as pastures succeed to secondary forest, the total number of bird species using these habitats increases dramatically. The numbers of frugivorous and restricted-range bird species exhibit a similar increase. Although there was a successional increase in number of bird species, fewer than $50 \%$ of the total number of bird species observed at the forest 50 site were recorded in pasture 6 (which has a structurally complex vegetation). Clearly, abandoned pastures remain suboptimal habitats for several years. Nevertheless, some rare and threatened species use them.

My data also show clear temporal trends in guild structure for abandoned pastures confirming the trend in avian frugivore use of pastures identified by Da Silva et al. (1996) in Amazonia. For example, the number of frugivores recorded increase from just 3 species in pasture 2 to 12 in pasture 6 . In fact, pasture 6 had similar numbers as those recorded at the forest 20 site. The floristic diversity and availability of fruit in secondary Andean forest might be similar to pastures abandoned for 5-6 years. Only White-throated Quail-Dove Geotrygon frenata and the Blue-and-Black Tanager Tangara vassorii recorded in forest 20 were not documented in pasture 5 or 6 . There was also a trend toward larger species and more forest-dwelling species in the older pastures. More forest-dwelling species (e.g. guans, fruiteaters, quetzals) were recorded in older pastures than species tolerant of open pasture (Hilty and Brown 1986; Fjeldså and Krabbe 1990). Nevertheless, several species appear to be quite ubiquitous, e.g. Speckled Hummingbird Adelomyia melanogenys, Turquoise Jay Cyanolyca turcosa, and Chestnut-crowned Antpitta.

These data have conservation significance because two restricted-range species of least concern and three near-threatened species were recorded within the abandoned pastures during the survey. Typically Violet-tailed Sylphs Aglaiocercus coelestis occupy wet forest and are occasional at forest borders (Hilty and Brown 1986) yet they were recorded well within pasture 5. Dusky-bellied BushTanagers Chlorospingus semifuscus were common, being recorded at all sites except pastures 1 and 2. Similarly, Toucan Barbet Semnornis ramphastinus and Plate-billed Mountain-Toucan Andigena laminirostris, although restricted-range and near-threatened, were recorded at all sites except pastures 1 and 2. Although both species frequent forest borders (Hilty and Brown 1986), they were observed in pastures 5 and 6. In fact, Violet-tailed Sylph, Plate-billed Mountain-Toucan, and Toucan Barbet use forest edge, while Dusky-bellied Bush-Tanager also frequent clearings (Stattersfield et al. 1998). Furthermore, according to Hilty and Brown (1986) Dark-backed Wood-Quail Odontophorus melanonotus is typical of 
montane forest yet it was recorded in pasture 6. In addition to those species recorded entirely within each abandoned pasture, two restricted-range species, Giant Antpitta Grallaria gigantea and Gorgeted Sunangel Heliangelus strophianus were recorded at the very edge of pastures 2 and 6 (T. Nunnery 1999 in litt.). In eastern Ecuador, the Giant Antpitta is a regular visitor to secondary forest and pastures (Ridgely and Tudor 1994). One near-threatened species, Beautiful Jay Cyanolyca pulchra was recorded in pasture 5 prior to the survey period, and one vulnerable species, the Tanager-Finch Oreothraupis arremonops was recorded in the border of pasture 5. The increase in the number of restricted-range species recorded as abandoned pastures convert to secondary forest, even though little primary forest exists in the Tandayapa valley, is very promising. These data indicate that these restricted-range species are tolerant of edge and more open habitat than previously suspected.

These nine restricted-range species may be using abandoned pastures because so little suitable primary forest remains in the valley, in primary forest they may use edges or clearings, which abandoned pastures resemble. Abandoned pastures may represent a vital resource throughout the Andes for restricted-range species where deforestation is widespread. Moreover, such pastures offer excellent views of birds, and might be considered by a perceptive ecotourist lodge owner as a good investment both in the short term for viewing restricted-range bird species and in the long term as they revert to optimal forest habitat.

In conclusion, abandoned pastures rapidly convert to forest and are used by forest birds even where pristine forest constitutes less than 10\% of the total area. Restricted-range bird species typical of forests will eventually colonize these pastures. Kappelle (1993) found that within 35 years of clear-cutting Quercus forest in Costa Rica, $70 \%$ of the original tree species had returned. The long-term prospects for abandoned pastures are therefore good. Conservation efforts could usefully be directed towards them because they represent an investment in the future of the bird fauna as they revert to a forested state.

\section{Acknowledgments}

I am grateful to the editor, Chris Mason, Niels Krabbe, Paul Greenfield, and C. Ray Chandler for constructive comments on the revised manuscript, and to Georgia Southern University for financial support. I also thank Tony Nunnery for his assistance in confirming the identification of many bird calls and songs, and Richard Parsons and Niels Krabbe for allowing access to their property. Thanks must also go to Chuck Trupe for helping me modify and draft Figure 1.

\section{References}

Andrade, G. I. and Rubio-Torgler, H. (1994) Sustainable use of tropical rain forest: evidence from the avifauna in a shifting-cultivation habitat mosaic in the Colombian Amazon. Conserv. Biol. 8: 545-554.

Borges, S. H. and Stouffer, P. C. (1999) Bird communities in two types of anthropogenic successional vegetation in central Amazonia. Condor 101: 529-536.

Best, B. J., Heijnen, T and Williams R. S. R. (1996) A guide to bird-watching in Ecuador and the Galápagos Islands. West Yorkshire: Biosphere Publications. 
Caufield, C. (1986) In the rainforest. Chicago: University of Chicago Press.

Da Silva, J. M. C., Uhl, C. and Murray, G. (1996) Plant succession, landscape management, and the ecology of frugivorous birds in abandoned Amazonian pastures. Conserv. Biol. 10: 491-503.

Finegan, B. (1992) The management potential of neotropical secondary lowland rain forest. Forest Ecol. and Manage. 47: 295-321.

Fjeldså, J. and Krabbe, N. (1990) Birds of the High Andes. Svendborg: Zoological Museum, University of Copenhagen and Apollo Books.

Guevara, S., Meave, J., Morenocasasola, P. and Laborde, J. (1992) Floristic composition and structure of vegetation under isolated trees in Neotropical pastures. J. Veg. Sci. 3: 655-664.

Hilty, S. L. and Brown, W. L. (1986) A guide to the birds of Colombia. Princeton, NJ: Princeton University Press.

Kappele, M. (1993) Recovery following clearing of an Upper Montane Quercus Forest in Costa Rica. Rev. Biol. Tropical 41: 47-56.

Parker, T A. (1991) On the use of tape recorders in avifaunal surveys. Auk 108: 443-444.

Poulsen, B. O. and Krabbe, N. (1997) Avian rarity in ten cloud-forest communities in the Andes of Ecuador: implications for conservation. Biodiv. Conserv. 6: 1365-1375.

Ridgely, R .S. and Tudor, G. (1994) Birds of South America: volume II, the Suboscine Passerines. Princeton: Princeton University Press.

Salaman, P. G. W. (1994) Surveys and conservation of biodiversity in the Choco, south-west Colombia. Cambridge, UK: Birdlife International (Study Report 61).

Sarmiento F. O. (1997) Arrested succession in pastures hinders regeneration of Tropandean forests and shreds mountain landscapes. Environ. Conserv. 24: 14-23.

Schelhas, J. and Greenberg, R. (1986) Introduction: The value of forest patches. Pp. xvxxxvi in J. Schelhas and R. Greenberg, eds. Forest patches in Tropical landscapes. Washington, DC: Island Press.

Stattersfield, A. J., Crosby, M. J., Long, A. J., and Wege, D. C. (1998) Endemic bird areas of the world. Cambridge, U.K.: BirdLife International (Conservation Series 7).

Thomlinson, J. R., Serrano, M. I., Lopez, T. D., Aide, T. M. and Zimmerman, J. K. (1996) Land-use dynamics in a post-agricultural Puerto Rican Landscape (1936-1088). Biotropica 28: 525-536.

Uhl, C., Buschbacher, R. and Serrao, E. A. S. (1988) Abandoned pastures in eastern Amazonia. I. Patterns of plant succession. J.Ecol. 76: 663-681.

Wilson, E. O. (1992) The Diversity of life. New York: Norton.

MARK R. WELFORD

Dept. of Geology and Geography, Georgia Southern University, Statesboro, Georgia, 30460-8149, U.S.A. E-mail: mwelfgeog@gsvms2.cc.gasou.edu 
